\title{
Pelaksanaan Program Redistribusi Tanah Di Kawasan Tanah Adat Provinsi Papua
}

\author{
Yudhistira Setya Wardhana ${ }^{凶}$, \\ Kantor Pertanahan Kabupaten Paniai \\ E-mail: yudhistira.swardha@atrbpn.go.id
}

\begin{abstract}
Agrarian reform or Agrarian Reform as an issue, is complex and multidimensional which is a major program of the Indonesian state in realizing the welfare of the Indonesian people, especially in terms of increasing access of poor peasants to land tenure in Indonesia, but implementing agararial reform is not an easy thing, with many obstacles, both from the legal, land administration, social, political, cultural and security aspects. Agrarian Reform (Agrarian Reform) or land reform is one of the effective tools or ways to achieve successful development, because access to land is fundamental for socio-economic development, poverty reduction, and environmental sustainability, apart from being a factor of production, land is also a factor of wealth, prestige and strength or power. In this perspective, land redistribution not only results in an increase in economic assets owned by poor farmers, but also an increase in political power and social participation, thus, the implementation of agrarian reform is not only aimed at reducing poverty and unemployment, but also in order to eliminate inequality, especially in political and social fields. The Land Redistribution Program in Papua Province itself, as the author sees its implementation, does not pay attention to regulations higher than Presidential Decree Number 86 of 2018. This is also reinforced by Article 18B paragraph (2) of the 1945 Constitution which states that the state recognizes and respects customary law community units. along with their traditional rights as long as they are still alive and in accordance with the development of society and the principles of the Unitary State of the Republic of Indonesia. In addition, Article 3 of the UUPA does contain the term "ulayat rights and rights similar to that".
\end{abstract}

Keywords: Inconsistency, Ulayat Land, Land Redistribution

\section{Abstrak}

Reforma agraria atau Pembaruan Agraria sebagai suatu isu, bersifat kompleks dan multidimensi yang merupakan suatu program besar dari negara Indonesia dalam mewujudkan kesejahteraan masyarakat Indonesia, terutama dalam hal peningkatan akses kaum tani miskin terhadap penguasaan tanah di Indonesia, namun dalam melaksanakan reforma agararia tersebut bukanlah suatu hal yang mudah, banyak hambatannya, baik dari aspek hukum, administrasi pertanahan, sosial, politik, budaya, dan keamanan. Reforma Agraria (Pembaruan Agraria) atau land reform merupakan salah satu alat atau cara efektif untuk mewujudkan keberhasilan pembangunan, sebab akses terhadap tanah merupakan suatu yang sifatnya fundamental bagi pembangunan sosial ekonomi, pengurangan kemiskinan, dan bagi kelestarian lingkungan yang berkelanjutan, selain sebagai faktor produksi, tanah juga merupakan faktor kekayaan, prestise dan kekuatan atau kekuasaan. Dalam persfektif ini redistribusi tanah tidak hanya menghasilkan peningkatan aset ekonomi yang dimiliki oleh petani miskin, tetapi juga peningkatan kekuatan politik dan partisipasi sosial, dengan demikian, pelaksanaan reforma agraria tidak hanya ditujukan untuk mengurangi kemiskinan dan pengangguran, tetapi juga dalam rangka menghapus kesenjangan, terutama dalam bidang politik dan social. Program Redistribusi Tanah di Provinsi Papua sendiri sebagaimana Penulis lihat pelaksanaanya tidak memperhatikan pada peraturan yang lebih tinggi dari Perpres Nomor 86 Tahun 2018. Hal ini juga diperkuat dengan Pasal 18B ayat (2) UUD 1945 menyatakan bahwa negara mengakui dan menghormati kesatuan-kesatuan masyarakat hukum adat beserta hak-hak tradisionalnya sepanjang masih hidup dan sesuai dengan perkembangan masyarakat dan prinsip Negara Kesatuan Republik Indonesia Selain itu, dalam Pasal 3 UUPA memang terdapat istilah "hak ulayat dan hak-hak yang serupa dengan itu".

Kata Kunci: Inkonsistensi, Tanah Ulayat, Redistribusi Tanah 


\section{Pendahuluan}

Indonesia adalah negara hukum. Pengakuan demikian termaktub dalam Pasal 1 ayat (3) Undang-Undang Dasar Negara Republik Indonesia Tahun 1945 (selanjutnya disebut UUD 1945). Sebagai negara hukum, segala aspek kehidupan baik dalam bidang kemasyarakatan, pemerintahan, dan kenegaraan harus senantiasa berdasarkan atas hukum yang bersumber pada pancasila dan UUD 1945. Dalam rangka mewujudkan cita-cita negara hukum, maka diperlukan pembangunan sistem hukum yang tertib dan terarah.

Gagasan negara hukum (the rule of law) hanya dapat tumbuh dan berkembang dalam masyarakat yang demokratis (democratic rule of law). Sebaliknya, demokrasi tidak akan tumbuh sehat jika tidak didasarkan atas hukum (konstitusi) dan diiringi oleh tegaknya 'rule of law' (constitutional democracy). Prinsip-prinsip 'the rule of law' itu sendiri harus pula diiringi oleh tegak dan berfungsinya 'the rule of ethics' secara bersamaan, sehingga tata-kelola kekuasaan negara, tata-kelola organisasi-organisasi dunia usaha dan organisasi masyarakat madani pada umumnya dapat tumbuh dan berkembang sesuai dengan prinsip modern, yaitu 'good governance ${ }^{1}$

Terdapat korelasi yang jelas antara negara hukum, yang bertumpu pada konstitusi dan peraturan perundang-undangan, dengan kedaulatan rakyat, yang dijalankan melalui sistem demokrasi. Dalam sistem demokrasi, penyelenggaraan negara itu harus bertumpu pada partisipasi dan kepentingan rakyat. Implentasi negara hukum itu harus ditopang dengan sistem demokrasi. Hubungan antara negara hukum dan demokrasi tak dapat dipisahkan. Demokrasi tanpa pengaturan hukum akan kehilangan bentuk dan arah, sedangkan hukum tanpa demokrasi akan kehilangan makna. Demokrasi merupaka $f$ n cara paling aman untuk mempertahankan kontrol dalam negara hukum. Dengan demikian, negara hukum yang bertopang pada sistem demokrasi dapat disebut sebagai negara hukum demokrasi ${ }^{2}$

Kondisi Negara Hukum Indonesia dewasa ini sangat memprihatinkan. Hukum diperlukan agar kebijakan-kebijakan kenegaraan dan pemerintahan dapat memperoleh bentuk resmi yang bersifat mengikat dan dapat dipaksakan berlakunya untuk umum. Karena hukum yang baik kita perlukan dalam rangka pembuatan kebijakan (policy making) yang diperlukan merekayasa, mendinamisasi, mendorong, dan bahkan mengarahkan guna mencapai tujuan hidup bersama dalam wadah Negara Kesatuan Republik Indonesia yang berdasarkan Pancasila dan UUD 1945. Di samping itu, dalam rangka pelaksanaan kebijakan-kebijakan tersebut (policy executing), hukum juga harus difungsikan sebagai sarana pengendali dan sebagai sumber rujukan yang mengikat dalam menjalankan segala roda pemerintahan dan kegiatan penyelenggaraan negara.

Namun dalam kenyataan praktik, baik dalam konteks pembuatan kebijakan (policy making) maupun dalam konteks pelaksanaan kebijakan (policy executing), masih terlihat adanya gejala anomi dan anomali yang belum dapat diselesaikan dengan baik selama 22 tahun pasca reformasi ini. Dari segi sistem norma, perubahan-perubahan telah terjadi dimulai dari norma-norma turunan dalam konstitusi negara yang mengalami perubahan mendasar. Dari segi materinya dapat dikatakan sudah sesuai tapi pada saat pelaksanaanya telah mengalami perubahan 300 persen dari isi aslinya sebagaimana diwarisi dari tahun 1945.(Asshidiqie,2015, ' $P^{\prime}$ 4)

Eksistensi tanah dalam kehidupan manusia mempunyai arti dan juga memiliki fungsi ganda, yaitu sebagai sosial asset dan capital asset. Sebagai social asset tanah merupakan sarana pengikat kesatuan sosial di kalangan masyarakat untuk hidup dan kehidupan, sedangkan capital asset tanah merupakan faktor modal dalam pembangunan dan telah tumbuh sebagai benda ekonomi yang sangat penting, sekaligus sebagai bahan perniagaan dan objek spekulasi.(Ivan \& Jamin,2015)

Tanah sebagai benda yang bersifat "konstan" (tidak dapat bertambah) banyak menimbulkan masalah, permasalahan dibidang pertanahan ini dapat berupa sengketa atau konflik tentang kepemilikan, penguasaan, penggunaan dan pemanfaatannya.Sengketa atau

Jimly Asshiddiqie, “The Rule Of Law” di Indonesia Pasca Reformasi”,Sinar grafika, Jakarta,2015,hlm.2

Jimly Asshiddiqie," Negara Hukum Indonesia", http://www.jimly.com, diakses pada tanggal 3 Maret 2015, hal.4. 
konflik tentang kepemilikan, penguasaan, penggunaan dan pemanfaatan suatu bidang tanah dapat terjadi baik itu antara orang perseorangan, kelompok, golongan, organisasi, badan hukum atau lembaga.

Instrumen pendaftaran tanah yang berlaku sekarang belum mengakomodasi keragaman tenurial di masyarakat hukum adat yang bersifat komunal. PP No. 24 Tahun 1997 tentang pendaftaran tanah, begitu juga PP No.10 tahun 1961 yang berlaku sebelumnya, belum mampu memecahkan persoalan sertifikat tanah-tanah milik bersama yang merupakan ciri khas masyarakat hukum adat. Ketentuan ini justru ingin menyeragamkan bentuk- bentuk tenurial di seluruh Indonesia dengan menentukan jenis-jenis hak atas tanah yang bisa disertifikasi.

Di Papua, sengketa di bidang pertanahan sering terjadi dalam hal peralihan hak atas tanah ulayat menjadi hak milik perorangan melalui jual beli dengan pelepasan adat. Surat pelepasan tanah adat merupakan tanda bukti atas sebidang tanah adat yang telah mengalami peralihan atau pelepasan hak atas tanah, yang dibuat oleh Lembaga Masyarakat Adat sebagai pihak yang berwenang sebagaimana diatur dalam Ketentuan pasal 43 ayat (4) Undang-Undang nomor 21 Tahun 2001 tentang Otonomi Khusus Bagi Provinsi Papua.Selain sebagai tanda bukti beralihnya hak atas tanah ulayat, surat pelepasan tanah adat juga sebagai salah satu syarat pendaftaran tanah dalam rangka penerbitan sertifikat tanah di Kantor Pertanahan.(Maria Fanisa Gefilem, 2016:82). Begitu pula ketika melakukan kegiatan reforma agraria Negara telah merespon penguasaan tanah adat oleh masyarakat adat yang selama ini masih exis, dengan diterbitkan Perka BPN No.9 tahun 2015 maka lahirlah satu jenis sertifikat baru yang disebut dengan sertifikat hak komunal. Keberadaan sertifikat hak komunal dalam bingkai hukum UUPA dan PP No. 24 Tahun 1997 merupakan konsep hukum baru yang menjawab persoalan kepastian hukum penguasaan tanah adat oleh masyarakat adat. Namun dalam tataran teori, keberadaan sertifikat hak komunal terjadi kekosongan hukum dimana sertifikat yang dikenal oleh UUPA dan PP No. 24 tahun 1997, tanah adat bukan merupakan objek pendaftaran tanah, selain itu konsep hak komunal yang tdak sesuai dengan Pasal 3 UUPA, yang hanya mengenal hak ulayat menimbulkan ketidakpastian hukum dasar hukum dari keberadaan hak komunal sebagai jenis hak baru yang diatur dalam Perka BPN No. 9 Tahun 2015 sebagaimana yang telah diperbaharui oleh Permen ATR/BPN No.10 Tahun 2019. ${ }^{3}$

Pelaksanaan reforma agraria di Provinsi Papua tidak konsisten, suatu kepemilikan tanah diakui sebagai tanah Negara, lebih sering tanah adat diperlakukan sebagai tanah Negara. Menurut Kurnia Warman dalam buku Hukum Agraria Dalam Masyarakat Majemuk (hal. 40) persyaratan yang harus dipenuhi oleh hak ulayat menurut Pasal 3 UUPA adalah:

1. Sepanjang kenyataannya masyarakat hukum adat itu masih ada.Mengenai hal ini, sesuai dengan Penjelasan Pasal 67 ayat (1) Undang-Undang Nomor 41 Tahun 1999 tentang Kehutanan, suatu masyarakat hukum adat diakui keberadaannya, jika menurut kenyataannya memenuhi unsur antara lain:

a. masyarakatnya masih dalam bentuk paguyuban (rechtsgemeenschap);

b. ada kelembagaan dalam bentuk perangkat penguasa adatnya;

c. ada wilayah hukum adat yang jelas;

d. ada pranata dan perangkat hukum, khususnya peradilan adat, yang masih ditaati; dan

e. masih mengadakan pemungutan hasil hutan di wilayah hutan sekitarnya;

2. Sesuai dengan kepentingan nasional dan negara.

Dari segi politik, menurut Kurnia Warman, pernyataan "sesuai dengan kepentingan nasional dan negara, yang berdasarkan atas persatuan bangsa" merupakan suatu a priori yang mengandung kecurigaan dari pemerintah terhadap masyarakat hukum adat. Pernyataan ini menunjukan seolah-olah masyarakat hukum adat itu bukan merupakan bagian kenasionalan, kenegaraan dan kebangsaan. Maka karena

Maria Fanisa Gefilem, Pelepasan Tanah Adat Suku Moi Di Kota Sorong Provinsi Papua Barat Berdasarkan Peraturan Pemerintah Nomor 24 Tahun 1997 Tentang Pendaftaran Tanah".Lex Crimen Vol. V/No. 3/Mar/2016,2016,hlm.82 
pernyataan "sesuai dengan kepentingan negara" ini dapat menimbulkan multitafsir dan sarat kepentingan politik. Akan sulit bagi kita untuk dapat menentukan apakah keberadaan suatu masyarakat hukum adat tertentu memenuhi persyaratan ini atau tidak, tanpa mengetahui masyarakat hukum adat yang mana yang dimaksud tersebut.

3. Tidak bertentangan dengan undang-undang dan peraturan yang lebih tinggi. Persyaratan yang terakhir ini, menurut Kurnia Warman, tidak terlampau menjadi ganjalan yang merisaukan bagi keberadaan hak ulayat, karena UUD 1945 telah tegas mengakui keberadaan hak-hak tradisional komunitas di Indonesia. Pasal 18B ayat (2) UUD 1945 menyatakan bahwa negara mengakui dan menghormati kesatuan-kesatuan masyarakat hukum adat beserta hak-hak tradisionalnya sepanjang masih hidup dan sesuai dengan perkembangan masyarakat dan prinsip Negara Kesatuan Republik Indonesia. ${ }^{4}$

4. Hal demikian juga diatur pada Perpres No.86 Tahun 2018 dimana objek redistribusi tanah ialah jelas pada Pasal 7 Perpes No.86 Tahun 2018 tidak disebutkan tanah adat sebagai objek redistribusi tanah. beradasarkan permasalahan diatas maka fokus penelitian ini membahas mengenai inkonsistensi pelaksanaan program redistribusi tanah di kawasan tanah adat Provinsi Papua (berdasarkan Pasal 18 B Ayat 2 UUD 1945 Jo Pasal 3 UUPA No.5 Tahun 1960).

\section{Metode Penelitian}

Metode pendekatan yang digunakan dalam penelitian ini adalah yuridis normatif atau penelitian hukum yang hanya meneliti bahan pustaka sehingga disebut juga penelitian hukum kepustakaan. Dalam penelitian dengan pendekatan yuridis normatif peneliti mengkonsepsikan hukum sebagai suatu system normatif yang bersifat otonom,tertutup, dan lepas dari kehidupan hukum masyarakat.

Di dalam penelitian hukum terdapat beberapa pendekatan. Dengan pendekatan tersebut, peneliti akan mendapat informasi dari berbagai aspek mengenai isu yang akan dicoba untuk dicari jawabanya. Adapun beberapa pendekatan yang digunakan di dalam penelitian hukum adalah pendekatan undang-undang (statute approach), pendekatan kasus (case approach), pendekatan historis (historical approach), pendekatan komparatif (comparative approach), dan pendekatan konseptual (conceptual approach). ${ }^{5} \quad$ Merujuk pada pendekatan tersebut dalam penelitian yuridis normatif ini ada 4 pendekatan yang digunakan sebagai berikut:Pendekatan Filsafat (Philosophi Approach).

Penelitian dilakukan di Kanwil Provinsi Papua dan Kantor Pertanahan Kabupaten Paniai. Untuk memecahkan isu hukum dan sekaligus memberikan deskritif mengenai apa yang seyogyanya, maka diperlukan sumber bahan hukum dalam melakukan penelitian. Adapun dalam penelitian ini peneliti menggunakan sumber bahan hukum berupa bahan hukum primer, bahan hukum sekunder dan bahan hukum tertier. 6 Bahan hukum yang diperoleh dan diinventarisir akan dianalisis secara normatif kualitatif, normatif disini maksudnya penelitian ini bertitik tolak pada peraturan-peraturan yang berupa peraturan perundangundangan,yurisprodensi, dan ajaran atau doktrin yang ada sebagai norma hukum positif. Sedangkan kualitatif yaitu analisis yang dilakukan dengan cara memahami dan merangkai bahan hukum yang telah dikumpulkan dan disusun secara sistematis dan diuraikan dengan secara bermutu dalam kalimat yang teratur, runtut, dan logis, kemudian ditarik kesimpulan.

Adi Candro Bawono, Pengakuan Hak Ulayat, Hukum Online,Jakarta,2019,hlm.1

Peter Mahmud Marzuki, Penelitian Hukum, Kencana, Jakarta, 2013,hlm.133.

Soerjono Soekanto dan Sri Mamudji, Penelitian Hukum Normatif, PT Raja Grafindo Persada, Jakarta,2012,hlm.13. 
Kosmik Hukum Vol. 20 No. 1 (2020): 64-71

E-ISSN: 2655-9242 | P-ISSN: 1411-9781

DOI: 10.30595/kosmikhukum.v20i1.8625

\section{Hasil dan Pembahasan}

\section{Redistribusi Tanah Di Kawasan Tanah Adat}

Adat-istiadat mempunyai ikatan dan pe-ngaruh yang kuat dalam masyarakat. Kekuatan mengikat tergantung pada masyarakat yang mendukung adat-istiadat tersebut, terutama berpangkal tolak pada perasaan kebersamaan, idealisme dan keadilan. Sulit untuk dibayangkan bahwa adat-istiadat walaupun dipelihara terus-menerus, dengan sendirinya akan mewujudkan kepastian hukum jika terdapat kai-dah-kaidah mengikat yang mengatur tata kehidupan masa kini dan masa yang akan datang.

Istilah masyarakat hukum adat sebetulnya masih sering menjadi topik perdebatan hingga kini. Sebahagian kalangan memandang masyarakat hukum adat mengandung kerancuan antara "MasyarakatHukum Adat" dengan "Masyarakat Hukum-Adat". .Istilah MasyarakatHukum Adat menekankan pada "Masyarakat hukum", dan istilah Masyarakat Hukum-Adat menekankan pada Hukum Adat . ${ }^{7}$

Dilain pihak ada juga yang berpendapat bahwa Masyarakat Hukum Adat hanya mereduksi masyarakat adat dalam dimensi hukum saja . Padahal masyarakat adat juga bergantung pada dimensi lainnya, seperti dimensi sosial, politik, agama, budaya,ekologi dan ekonomi. Secara sederhana, tidak semua masyarakat adat memiliki instrumen yang bisa dikualifikasikan sebagai hukum tetapi mereka tetap memiliki hak-hak tradisional atau hak-hak adat yang didasarkan pada hubungan kesejarahan dan norma-norma lokal yang luhur dari interaksi yang panjang. Sehingga seharusnya konstitusi negara tidak membeda-bedakan antara Masyarakat Adat dengan Masyarakat Hukum Adat. ${ }^{8}$

Meskipun di dalam Pasal 3 UUPA terdapat istilah menyebut tentang Masyarakat Hukum Adat, tanpa memberikan penjelasan lebih lanjut mengenai pengertiannya. Bahkan dalam berbagai kesempatan dalam memori Penjelasan sering digunakan istilah Masyarakat Hukum, yang dimaksud adalah masyarakat Hukum Adat yang disebut secara eksplisit dalam Pasal 3 tersebut.

Secara teoretis, pengertian Masyarakat Hukum dan masyarakat Hukum Adat adalah berbeda. Kusumadi Pujosewojo (1971) mengartikan masyarakat hukum sebagai suatu masyarakat yang menetapkan, terikat dan tunduk pada tata hukumnya sendiri. Sedangkan Masyarakat Hukum Adat adalah Masyarakat yang timbul secara spontan di wilayah tertentu yang berdirinya tidak ditetapkan atau diperintahkan oleh penguasa yang lebih tinggi atau penguasa lainnya, dengan atau solidaritas yang sangat besar diantara para anggotanya, yang memandang bukan anggota masyarakat sebagai orang luar dan menggunakan wilayahnya sebagai sumber kekayaan yang hanya dapat dimanfaatkan sepenuhnya oleh anggotanya.. Pemanfaatan oleh orang luar harus dengan izin dan pemberian imbalan tertentu berupa rekognisi dan lain-lain. ${ }^{9}$

Dapat disimpulkan bahwa hukum adat dimaknai dalam penulisan ini adalah hukum adat yang mengandung unsur-unsur memben-tuknya, seperti terdapat adat-istiadat sebagai nilai-nilai yang telah melembaga dalam masya-rakat melalui perbuatan-perbuatan masyarakat, mengandung norma yang disepakati bersama secara tidak tertulis, memiliki institusi atau organisasi yang menegakan, memiliki sanksi serta dipengaruhi oleh agama yang dianut pada masyarakat. Nilai-nilai dan norma-norma yang telah mendapatkan kesepakatan masa lalu, dalam kehidupan modern masih menjadi rujukan sebagai kearifan lokal (local wisdom).

Selanjutnya menurut penulis secara substansial memberikan pemahaman bahwa hukum adat merupakan hukum yang selalu hidup dan berkembang dalam masyarakat, yang selalu mengikuti perkembangan jaman, memberikan jaminan ketertiban bagi masyarakat, serta mampu memberikan keadilan. Hukum adat ber-tujuan menciptakan kedamaian dan memajukan kesejahteraan bagi warga masyarakat. Sedang-kan hak masyarakat hukum adat merupakan hak bersifat individu maupun hak yang bersifat komunal. Salah satu hak yang

\footnotetext{
Suryaman Mustari Pide, Hukum Adat Dahulu,Kini, dan Akan Datang, Kencana,Jakarta,2017,hlm.120

Rosmidah, Pengakuan Hukum Terhadap Hak Ulayat Masyarakat Hukum Adat Dan Hambatan Implementasinya, Jurnal Digest Epistema Berkala Isu Hukum dan Keadilan Eko-sosial,2015,.hlm.95
}

$9 \quad$ Loc.cit 
bersifat komunal. yang terdapat dalam UUPA adalah hak ulayat (wilayah) untuk menunjukan kepada tanah yang merupakan wilayah lingkungan masyarakat hukum bersangkutan.

Masyarakat yang memperkembangkan ciri-ciri khas hukum adat (komunal, ikatan batin yang kuat antar anggota baik yang dikarenakan faktor geneologis, teritorial dan geneologis teritorial.) itulah yang disebut masyarakat hukum adat. Dengan demikian, hak ulayat menunjukkan hubungan hukum antara masyarakat hukum (subyek hak) dan tanah/wilayah tertentu (obyek hak). Hak ulayat tersebut berisi wewenang untuk:

1) Mengatur dan menyelenggarakan penggunaan tanah (untuk pemukiman, bercocok tanam dan lain-lain) persediaan (pembuatan pemukiman/persawahan baru dan lainlain) dan pemeliharaan tanah;

2) Mengatur dan menetukan hubungan hukum antara orang dengan tanah (memberikan hak tertentu pada subyek tertentu;

3) Mengatur dan menetapkan hubungan hukum antara orang-orang dan perbuatan perbuatan hukum yang berkenaan dengan tanah (jual-beli, warisan dan lain-lain).

Isi wewenang hak ulayat tersebut menyatakan, bahwa hubungan antara masyarakat hukum adat dengan tanah/wilayahnya adalah hubungan menguasai, bukan hubungan milik sebagaimana halnya dalam konsep hubungan antara negara dengan tanah menurut Pasal 33 ayat (3) UUD 1945. Dengan demikian UUPA memberikan pengakuan bersyarat terhadap hak ulayat yaitu: pertama, syarat eksistensinya (keberadaannya) yakni tanah hak ulayat diakui sepanjang menurut kenyataannya masih ada. Artinya bahwa di daerah yang semula ada tanah hak ulayat, namun dalam perkembangan selanjutnya, hak milik perorangan menjadi kuat, sehingga menyebabkan hilangnya tanah hak ulayat, maka tanah hak ulayat tidak akan dihidupkan kembali. demikian pula di daerah-daerah yang tidak pernah ada tanah hak ulayat, tidak akan dilahirkan tanah hak ulayat yang baru. Kedua, syarat pelaksanaannya yaitu sesuai dengan kepentingan nasional dan negara yang berdasar atas persatuan bangsa serta tidak boleh bertentangan dengan undang-undang dan peraturan lainnya yang lebih tinggi. ${ }^{10}$

Di samping itu UUPA tidak memberikan kriteria mengenai eksistensi hak ulayat itu. Namun, dengan mengacu pada pengertian-pengertian fundamental tersebut di atas, dapat dikatakan bahwa kriteria penentu masih ada atau tidaknya hak ulayat harus dilihat pada tiga hal yakni:

1) Adanya masyarakat hukum adat yang memenuhi ciri-ciri tertentu sebagai subyek hakm ulayat;

2) Adanya tanah/wilayah dengan batas-batas tertentu;

3) Adanya kewenangan masyarakat hukum adat untuk melakukan tindakan-tindakan tertentu.

Dipenuhinya ketiga persyaratan tersebut secara kumulatif, kiranya cukup obyektif sebagai kriteria penentu masih ada atau tidaknya hak ulayat, sehingga misalnya, walaupun ada masyarakat hukum dan ada tanah atau wilayahnya, namun apabila masyarakat hukum tersebut sudah tidak mempunyai kewenangan untuk melakukan tiga tindakan tersebut, maka hak ulayat dapat dikatakan sudah tidak ada lagi.

Berdasarkan ketentuan tersebut, hak masyarakat hukum adat haruslah benar-benar masih ada dan tidak diberikan peluang untuk diadakan kembali. Karena hal tersebut merupakan kehidupan yang secara khas timbul dari hubungan secara lahiriah dan batiniah ,turun-menurun dan tidak terputus antara masyarakat hukum adat dengan wilayahnya. Keberadaan tersebut harus diikuti dengan hubungan pemanfaatan antara tanah dan masyarakat. Sedangkan masyarakat yang dimaksud adalah sekelompok orang yang terikat oleh tatanan hukum adatnya, sebagai warga bersama suatu persekutuan hukum, karena kesamaan tempat tinggal atau karena keturunan yang dikenal dengan berbagai nama yang berbeda tiap daerah.

Masalah pertanahan merupakan salah satu sektor pembangunan yang memerlukan penanganan yang amat serius dan ekstra hati-hati dari pemerintah, karena tanah merupakan kebutuhan yang sangat vital bagi masyarakat, khususnya masyarakat yang menggantungkan

10 Adi Candro Bawono,Loc.cit 
hidup pada tanah, sebab posisi pemerintah dalam menangani permasalahan pertanahan dihadapkan pada masalah yang serba sulit. Pada sisi sebagai pemerintah, mempunyai kewajiban untuk melindungi, mengatur ketertiban dan kesejahteraan masyarakat, dan pada sisi lain, tuntutan akselarasi pembangunan ekonomi yang harus dipacu yang pada akhirnya membutuhkan tanah sebagai tempat pijakan segala aktivitas ekonomi tersebut . ${ }^{11}$

Tanah memiliki hubungan yang abadi dengan manusia. Pengaturan tentang penguasaan pemilikan tanah telah disadari dan dijalankan sejak berabad-abad lamanya oleh negara-negara di dunia. Perombakan atau pembaruan struktur keagrariaan terutama tanah dilakukan untuk meningkatkan kesejahteraan rakyat terutama rakyat tani yang semula tidak memiliki lahan olahan atau garapan untuk memiliki tanah. ${ }^{12}$

Pelaksanaan Landreform khususnya Pembagian Tanah/Redistribusi Tanah Obyek Landreform (TOL)/TORA merupakan implementasi amanat Undang-Undang Nomor 5 Tahun 1960 tentang Peraturan Dasar Pokok-pokok Agraria (UUPA) Pasal 7, 10, 17 dan 18. TORA dimaksud adalah "tanah yang karena ketentuan landreform dan/atau tanah yang telah ditegaskan menjadi obyek landreform untuk selanjutnya diredsitribusikan kepada petani penggarap", Obyek pembagian tanah/redistribusi Tanah Objek Landreform (TOL)/TORA sesuai ketentuan Perpres Nomor 86 Tahun 2018 tentang Reforma Agraria Pasal 1 ayat 4 jelas bahwa subjek Reforma Agraria yang disebut Tora adalah tanah yang dikuasai oleh negara dan/atau tanah yang telah dimiliki oleh masyarakat untuk diredistribusi atau dilegalisasi. Tanah Negara adalah tanah yang tidak dipunyai dengan sesuatu hak atas tanah sebagaimana dimaksud dalam Pasal 16 Undang-Undang Nomor 5 Tahun 1960 tentang Peraturan Dasar Pokok-Pokok Agraria, dan/atau tidak merupakan tanah ulayat

Masyarakat Hukum Adat, tanah wakaf, barang milik negara/daerah/desa atau badan usaha milik negara/badan usaha milik daerah, dan tanah yang telah ada penguasaan dan belum dilekati dengan sesuatu hak atas tanah. ${ }^{13}$

Reforma agraria yang selalu diartikan dengan pembaharuan agraria, yang sering juga dikaitkan dengan land reform merupakan suatu upaya untuk dapat meningkatkan kesejahteraan masyarakat Indonesia. Dengan kata lain, tujuan pokok dari reforma agrarian adalah penciptaan keadilan sosial yang ditandai dengan adanya keadilan agraria (agrarian ustice), peningkatan produktivitas, dan peningkatan kesejahteraan rakyat. Keadilan agraria itu sendiri dapat dimaknai sebagai suatu kondisi dimana struktur penguasaan tanah secara relatif tidak memperlihatkan ketimpangan, yang memberikan peluang bagi terciptanya penyebaran dan penguatan aktivitas perekonomian rakyat yang berbasis di pedesaan, dan kemudian menjadi basis bagi partisipasi aktif (dan produktif) bagi sebagian besar penduduk yang nyatanya bergantung pada aktivitas pertanian untuk terlibat dalam kegiatan pembangunan nasional, baik secara sosial, ekonomi, maupun politik. ${ }^{14}$

Konsep Reforma Agraria pada hakekatnya merupakan konsep land reform, yang merupakan penataan kembali struktur penguasaan/ kepemilikan tanah yang lebih adil, termasuk pencegahan konsentrasi kepemilikan tanah. Land reform diartikan sebagai perombakan mengenai penguasaan dan pemilikan tanah serta hubungan-hubungan hokum yang bersangkutan dengan penguasaan tanah, untuk melaksanakan landreform, pemerintah harus merealisasikan ketentuan-ketentuan Pasal 7, Pasal 10, Pasal 13, dan Pasal 17 yang terkandung dalam Undang-Undang Pokok Agraria. Salah satu program yang digalakkan oleh pemerintah dalam rangka program land reform adalah redistribusi tanah. ${ }^{15}$

11 Fatimah, Reforma Agraria Dalam Konteks Peningkatan Akses Kaum Tani Miskin Terhadap Penguasaan Tanah di Indonesia, Jurnal Hukum Samudra Keadilan.Vol.10 No.2,2015,hlm.196

12 Sapradi, Redistribusi Tanah Negara Objek Landreform Dalam Mendukung Program Reforma Agraria Di kabupaten Sumbawa, Jurnal Kajian Hukum dan Keadilan,2015,hlm.365

13 Nia Kurniati, Penataan Penguasaan Tanah Milik Adat Melalui Pelaksanaan Kebijakan Land Reform (Studi Kasus di Kabupaten Buru Selatan), Jurnal Bina Hukum Vol.4 No.1,2019,hlm.157

14 Fatimah,Op.cit. hlm.199

15 Loc.cit 
Dalam Ketetapan MPR Nomor IX/TAP MPR/2001 tentang Pembaruan Agraria dan Pengelolaan Sumber Daya Alam, disebutkan bahwa pelaksanaan pembaruan agraria harus sesuai dengan prinsip-prinsip sebagai berikut:

1) memelihara dan mempertahankan keutuhan Negara Kesatuan Republik Indonesia;

2) menghormati dan menjunjung tinggi hak azasi manusia;

3) menghormati supremasi hukum dengan mengakomodasikan keaneka ragaman dalam unifikasi hukum;

4) mensejahterakan rakyat terutama melalui peningkatankualitas sumber daya manusia Indonesia;

5) mengembangkan, keputusan hakim, transparansi dan optimalisasi partisipasi rakyat;

6) mewujudkan keadilan dalam penguasaan, pemilikan, penggunaan, pemanfaatan dan pemeliharaan sumber daya agraria dan sumber daya alam;

7) memelihara keberlanjutan yang dapat memberi manfaat yang optimal baik untuk generasi sekarang maupun generasi mendatang, dengan tetap memperhatikan daya tampung dan dukundari keanekag lingkungan;

8) melaksanakan fungsi sosial, kelestarian dan fungsi ekologi sesuai dengan kondisi sosial budaya setempat;

9) meningkatkan keterpaduan dan koordinasi antar sektor pembanguanan dalam pelaksanaan pembaruan agraria;

10) mengakui dan menghormati hak masyarakat hukum adat dari keanekaragaman budaya bangsa atas sumber daya agrarian;

11)mengupayakan keseimbangan hak dan kewajiban negara, pemerintah (pusat, daerah provinsi, kabupaten/kota, dan desa yang setingkat), masyarakat dan individu;

12) melaksanakan desentralisasi berupa pembangunan kewenangan ditingkat nasional, daerah provinsi, kabupaten/kota dan desa atau yang setingkat berkaitan dengan alokasi dan managemen sumber daya agraria.

Dalam Rencana Pembanguanan Jangka menengah (RPJM) dan Rencana Pembanguanan Jangka Panjang (RPJPN) 2005-2025, disebutkan lima misi pokok di bidang pertanahan, yaitu;

1) Menerapkan sistem pengelolaan pertanahan yang efisien, efektif;

2) Melaksanakan penegakan hukum terhadap hak atas tanah dengan menerapkan prinsip-prinsip keadilan; transparansi, dan demokrasi;

3) Penyempurnaan penguasaan, pemilikan, penggunaan dan pemanfaatan tanah melaluinperumusan berbagai aturan pelaksanaan land reform, agar masyarakat golongan ekonomi lemah dapat lebih mudah mendapatkan hak atas tanah;

4) Penyempurnaan sistem hukum dan produk hukum pertanahan melalui inventarisasi dan penyempurnaan peraturan perundang-undangan pertanahan dengan mempertimbangkan aturan masyarakat adat;

5) Peningkatan upaya penyelesaian sengketa pertanahan.

Reforma agraria atau Pembaruan Agraria sebagai suatu isu, bersifat kompleks dan multidimensi yang merupakan suatu program besar dari negara Indonesia dalam mewujudkan kesejahteraan masyarakat Indonesia, terutama dalam hal peningkatan akses kaum tani miskin terhadap penguasaan tanah di Indonesia, namun dalam melaksanakan reforma agararia tersebut bukanlah suatu hal yang mudah, banyak hambatannya, baik dari aspek hukum, administrasi pertanahan, sosial, politik, budaya, dan keamanan. Oleh karena itu, negara perlu menyiapkan strategi untuk menerapkan program ini dengan efektif dan effisien, dengan mengacu kearah kebijakan reforma agararia sebagai berikut :

1) melakukan pengkajian ulang terhadap berbagai peraturan perundang-undangan yang berkaitan dengan agraria dalam rangka sinkronisasi kebijakan antar sektor demi terwujudnya peraturan perundang-undangan yang didasarkan pada prinsip-prinsip reforma agrarian;

2) melaksanakan penataan kembali penguasaan, pemilikan, penggunaan dan pemanfaatan tanah (landreform) yang berkeadilan dengan memperhatikan kepemilikan tanah untuk rakyat, baik tanah pertanian maupun tanah perkotaan; 
3) Menyelenggarakan pendataan pertanahan melalui inventarisasi dan registrasi penguasaan, pemilikan, penggunaan dan pemanfaatan tanah secara komprehensif dan sistematis dalam rangka pelaksanaan landreforom;

4) Menyelesaikan konflik-konflik yang berkenaan dengan sumber daya agraria yang timbul selama ini sekaligus dapat mengantisipasi potensi konflik dimasa mendatang

Guna menjamin terlaksananya penegakan hukum dengan didasarkan atas prinsipprinsip Reforma Agraria;

5) Memperkuat kelembagaan dan kewenanganya dalam rangka mengemban pelaksanaan pembaharuan agrarian dan menyelesaikan konflk-konflik yang berkenaan dengan sumber agrarian yang terjadi;

6) Mengupayakan pembiayaan dalam melaksanakan program pembaharuan agrarian dan pennyelesaikan konflik-konflik sumber daya agrarian yang terjadi.

Strategi pelaksanaan reforma agraria dalam konteks pembanguanan masyarakat Indonesia sangat diperlukan dengan mengacukan kebijakan agraria yang berupa regulasi agraria, melaksanaka penataan kembali dan landreform yang berkeadilan, menyelengarakan pendataan pertanahan, menyelesaikan konflik-konflik pertanahan, memperkuat kelembagaan dan kewenangan dari lembaga agraria, mengupayakan pembiayaan dalam reforma agraria. Namun, pada kenyataanya ialah wilayah papua merupakan wilayah adat Masyarakat Hukum Adat di Papua, termasuk di Papua Barat, terbagi di dalam 7 (tujuh) wilayah adat. Pertama, wilayah adat I Mamta di Kota Jayapura dengan 4 suku, Kabupaten Sarmi dengan 25 suku, Kabupaten Jayapura dengan 26 suku, Kabupaten Keeron dengan 14 suku dan Kabupaten Mamberamo 14 suku. Kedua, wilayah adat II Saireri: Kabupaten Biak 2 suku, Kabupaten Nabire 4 suku, Kabupaten Yapen 15 suku, Kabupaten Teluk Wondama 10 suku dan Kabupaten Waropen 10 suku. Ketiga, wilayah adat III Bomberai, Kabupaten Manokwari 6 suku, Kabupaten Raja Ampat 7 suku, Kabupaten Sorong 14 suku, Kabupaten Teluk Bintuni 7 suku, Kabupaten Sorong Selatan 6 suku. Keempat wilayah adat IV Bomberai, Kabupaten Fak-Fak 8 suku dan Kabupaten Kaimana 8 suku. Kelima, wilayah adat V AnimHa, Kabupaten Merauke 8 suku, Kabupaten Boven Digul 10 suku, Kabupaten Asmat 7 suku, Kabupaten Mappi 4 suku. Keenam wilayah adat VI La Pago, Kabupaten Pegunungan Bintang 4 suku, KabupatenYahukimo 6 suku, Kabupaten Jayawijaya 4 suku dan Kabupaten Tolikara 5 suku. Ketujuh wilayah adat VII Mee Pago, Kabupaten Timika 3 suku, Kabupaten Puncak Jaya 6 suku dan Kabupaten Paniai 3 suku. ${ }^{16}$

Reforma Agraria (Pembaruan Agraria) atau land reform merupakan salah satu alat atau cara efektif untuk mewujudkan keberhasilan pembangunan, sebab akses terhadap tanah merupakan suatu yang sifatnya fundamental bagi pembangunan sosial ekonomi, pengurangan kemiskinan, dan bagi kelestarian lingkungan yang berkelanjutan, selain sebagai faktor produksi, tanah juga merupakan faktor kekayaan, prestise dan kekuatan atau kekuasaan. Dalam persfektif ini redistribusi tanah tidak hanya menghasilkan peningkatan aset ekonomi yang dimiliki oleh petani miskin, tetapi juga peningkatan kekuatan politik dan partisipasi sosial, dengan demikian, pelaksanaan reforma agraria tidak hanya ditujukan untuk mengurangi kemiskinan dan pengangguran, tetapi juga dalam rangka menghapus kesenjangan, terutama dalam bidang politik dan sosial (Fatimah.2015,'P'193) ${ }^{17}$

Karena pada dasarnya Masyarakat Papua secara simbolik mengartikan tanah sebagai "dusun", "dapur", "tempat tumpah darah", dan tanah sebagai "ibu". Sedangkan secara religiusmagis, tanah memiliki nilai tertinggi dari sumber segala ciptaan dan penguasaan alam dan pemberian hidup dari Tuhan. Tanah menurut Orang Papua identik dengan kehidupan, maka diberi simbol sebagai seorang ibu atau mama yang selalu mengayomi, melindungi dan membesarkan seorang bayi, kanak-kanak sampai dewasa. Misalnya orang Kamoro menyebut 
tanah sebagai "Enai Tapare", orang Meybrat menyebut "Tabam Ramu" atau tanah kami/tanah ibu. ${ }^{18}$

\section{Inkonsistensi Redistribusi Tanah Di Kawasan Tanah Adat Papua}

Dalam kedudukanya sebagai dasar dan ideologi negara yang tidak dipersoalkan lagi bahkan sangat kuat, maka Pancasila itu harus dijadikan paradigma (kerangka berpikir, sumber nilai, dan orientasi arah) dalam pembangunan hukum, termasuk semua upaya pembaruaanya. Pancasila sebagai dasar negara memang berkonotasi yuridis dalam arti melahirkan berbagai peraturan perundangan yang tersusun secara hirarkhis dan bersumber darinya. Sedangkan Pancasila sebagai ideologi dapat dikonotasikan sebagai program sosial politik tempat hukum menjadi salah satu alatnya dan karenanya juga harus bersumber darinya.

Masalah ketidakpastian hak masyarakat hukum adat atas wilayah adatnya dalam hukum agraria Indonesia belum menemukan solusinya, baik pada tataran kebijakan hingga instrumen pemerintahan. Suatu jenis penguasaan Masyarakat Hukum Adat (MHA) atas keseluruhan wilayah adat, yang disebut sebagai "hak ulayat" dalam Undang-undang Pokok Agraria (UUPA) 1960 Pasal 3, dikategorikan bukanlah sebagai suatu hak atas tanah yang dapat diadministrasikan melalui pendaftaran tanah. Pemerintah tidak menyediakan suatu layanan yang dapat memberikan tanda kepemilikan tertentu, dan tidak memiliki peta resmi yang merupakan rujukan pengetahuan dimana saja keberadaan dari wilayah-wilayah adat itu di seantero Nusantara.

Sering dianggap bahwa penguasaan MHA atas wilayah adatnya, yang disebut "hak ulayat" atau bernama lain, akan hilang "dengan sendirinya" seiring perkembangan zaman, terutama karena menguatnya hak-hak individual atas tanah dari para anggota MHA. Pengakuan atas tanah ulayat di Papua bukan merupakan sesuatu yang baru diperbincangkan setelah perubahan kedua Undang-Undang Dasar Negara Republik Indonesia Tahun 1945 (UUD 1945), namun telah menjadi pemikiran dasar dari pembentukan Undang-Undang Nomor 21 Tahun 2001 tentang Otonomi Khusus Bagi Provinsi Papua (UU Otsus). Penyusun materi muatan RUU Otsus yang berasal dari kalangan akademisi di Papua telah memikirkan hal tersebut sebelum adanya Pasal 18B ayat (2) UUD 1945. Dalam ketentuan Pasal 43 UU Otsus mengatur bahwa:

1) Pemerintah Provinsi Papua wajib mengakui, menghormati, melindungi, memberdayakan dan mengembangkan hak-hak masyarakat adat dengan berpedoman pada ketentuan peraturan hukum yang berlaku;

2) Hak-hak masyarakat adat tersebut pada ayat (1) meliputi hak ulayat masyarakat hukum adat dan hak perorangan para warga masyarakat hukum adat yang bersangkutan;

3) Pelaksanaan hak ulayat, sepanjang menurut kenyataannya masih ada, dilakukan oleh penguasa adat masyarakat hukum adat yang bersangkutan menurut ketentuan hukum adat setempat, dengan menghormati penguasaan tanah bekas hak ulayat yang diperoleh pihak lain secara sah menurut tatacara dan berdasarkan peraturan perundang-undangan;

4) Penyediaan tanah ulayat dan tanah perorangan warga masyarakat hukum adat untuk keperluan apapun, dilakukan melalui musyawarah dengan masyarakat hukum adat dan warga yang bersangkutan untuk memperoleh kesepakatan mengenai penyerahan tanah yang diperlukan maupun imbalanya.

Pengaturan tersebut memiliki makna bahwa: Pertama, Pemerintah Provinsi Papua wajib mengakui, menghormati, melindungi, memberdayakan dan mengembangkan hak-hak masyarakat adat meliputi hak ulayat masyarakat hukum adat dan hak perorangan para warga masyarakat hukum adat dengan berpedoman pada peraturan perundang-undangan. Kedua,

18 Yusak Elisa Reba, Pengakuan Tanah Ulayat Di Papua dan kaitanya dengan Permen Hak Kumunal Atas Tanah, Jurnal Digest Epistema Berkala Isu Hukum dan Keadilan Eko-sosial, Vol.6/2016.2016,hlm.20 
Kosmik Hukum Vol. 20 No. 1 (2020): 64-71

E-ISSN: 2655-9242 | P-ISSN: 1411-9781

DOI: 10.30595/kosmikhukum.v20i1.8625

mekanisme musyawarah menyepakati penyediaan tanah ulayat dan tanah perorangan bagi kepentingan apapun yang disertai dengan pemberian imbalan. Ketiga, sarana mediasi sebagai suatu model yang digunakan dalam menyelesaikan sengketa tanah ulayat dan tanah perorangan bagi terwujudnya keadilan dan memuaskan pihak-pihak yang bersengketa. ${ }^{19}$

Hal demikian juga diperkuat dengan adanya Putusan Mahkamah Kontitusi Nomor 35/PUU-X/2012 Tentang Hutan Adat. Dalam pertimbangan putusannya, UUD 1945, yakni Pasal 18B ayat (2) dan Pasal 28I ayat (3) telah memberikan pengakuan dan perlindungan atas keberadaan hutan adat dalam kesatuan dengan wilayah hak ulayat suatu masyarakat hukum adat. Hal demikian merupakan konsekuensi pengakuan terhadap hukum adat sebagai "living law" yang sudah berlangsung sejak lama, dan diteruskan sampai sekarang. Oleh karena itu, menempatkan hutan adat sebagai bagian dari hutan negara merupakan pengabaian terhadap hak-hak masyarakat hukum adat, MK akhirnya memutuskan "hutan adat adalah hutan yang berada dalam wilayah masyarakat hukum adat", bukan sebagaimana mengartikan "hutan adat adalah hutan negara yang berada dalam wilayah masyarakat hukum adat" ${ }^{20}$

Penyelenggaraan reforma agraria di Indonesia diarahkan untuk melakukan perubahan struktur penguasaan, pemilikan, penggunaan, dan pemanfaatan tanah untuk menjamin terwujudnya keadilan dan kepastian hukum dalam penguasaan, pemilikan, penggunaan, dan pemanfaatan tanah (Martini,Ash-Shafikh,\& Afif,2019). Penyelenggaraan Reforma Agraria dalam Pasal 3 Perpres No. 86 Tahun 2018 tentang Reforma Agraria dilakukan oleh Pemerintah Pusat dan Pemerintah Daerah melalui tahapan perencanaan Reforma Agraria dan Pelaksanaan Reforma Agraria. Perencanaan ini dalam Pasal 4 meliputi perencanaan Penataan Aset terhadap penguasaan dan pemilikan tanah Objek Reforma Agraria (TORA), perencanaan terhadap penataan akses dalam penggunaan dan pemanfaatan serta produksi atas TORA, perencanaan kepastian hukum dan legislasi atas TORA, perencanaan penanganan Sengketa dan Konflik Agraria, dan perencanaan kegiatan lain yang mendukung Reforma Agraria.

Pelaksanaan Reforma Agraria di Indonesia menekankan pada konsep redistribusi tanah dengan membagikan tanah yang dikuasai Negara, tanah kelebihan luas maksimum, tanah absentee, dan tanah Negara lainnya yang telah ditetapkan menjadi tanah objek Reforma Agraria kepada petani penggarap dan petani lahan sempit. Namun secara garis besar dalam UU No. 86 Tahun 2018 tentang Reforma Agraria terdapat 3 hal utama dalam Reforma Agraria, yaitu penataan aset, penataan akses, dan penyelesaian sengketa. Hal ini sejalan dengan Strategi Nasional Pelaksanaan Reforma Agraria 2015-2019 yang antara lain meliputi: penguatan kerangka regulasi dan penyelesaian konflik agraria; penataan penguasaan dan pemilikan tanah objek Reforma Agraria (TORA); kepastian hukum dan legalisasi hak atas TORA; dan pemberdayaan masyarakat pemanfaatan TORA (RPJMN 2015, Luthfi 2018, Salim dan Utami 2019).

RUU Pertanahan akan mengatur mengenai Tanah Obyek Reforma Agraria (TORA). TORA merupakan tanah yang dikuasai oleh negara untuk didistribusikan atau diredistribusikan dalam rangka reforma agrarian (RUU Pertanahan). Adapun Pasal 49 RUU Pertanahan mengatakan bahwa TORA ini berasal dari:

1) Tanah negara yang berasal dari hapusnya hak atas tanah;

2) Tanah negara berasal dari tanah timbul;

3) Tanah negara berasal bekas pertambangan mineral, batubara, dan panas bumi sepanjang tidak merupakan barang milik negara yang telah tercatat dalam laporan keuangan pemerintah pusat;

4) Tanah negara berasal dari pelepasan kawasan hutan;

5) Tanah negara berasal dari tukar menukar atau perbuatan hukum keperdataan lainnya dalam rangka reforma agraria; atau

6) Tanah yang diserahkan oleh pemegang haknya kepada negara untuk reforma agraria.

19 Ibid,hlm.19

20 Lihat Putusan MK No.35/PUU-X/2012 
Putusan MK 35 menandai babak baru pengakuan negara terhadap masyarakat adat di Indonesia. Putusan tersebut mengakui masyarakat adat sebagai "penyandang hak" atau subjek hukum atas wilayah adatnya. Dengan itu hendak dikatakan bahwa Putusan MK 35 itu adalah suatu putusan yang menjadi dasar bagi suatu penataan kembali penguasaan tanah dan sumber daya alam yang selama ini berbasis kepada negara dan kepentingan swasta. Lebih lanjut, Putusan MK 35 juga menjadi dasar bagi pemulihan hak masyarakat adat yang selama ini mengalami tekanan dari pihak luar yang membuat mereka tidak bisa memperoleh manfaat secara maksimal dari wilayah, tanah dan sumber daya yang dimilikinya. ${ }^{21}$

Pada dasarnya, bumi dan air dan kekayaan alam yang terkandung di dalamnya dikuasai oleh negara dan dipergunakan untuk sebesar-besar kemakmuran rakyat. Ini termaktub dalam Pasal 33 ayat (3) Undang-Undang Dasar Negara Republik Indonesia 1945 (“UUD 1945"),Pengakuan hak ulayat juga terdapat pada Pasal 18B ayat (2) UUD 1945 yang menyatakan:Negara mengakui dan menghormati kesatuan-kesatuan masyarakat hukum adat beserta hak-hak tradisionalnya sepanjang masih hidup dan sesuai dengan perkembangan masyarakat dan prinsip Negara Kesatuan Republik Indonesia, yang diatur dalam undang-undang.

Lalu, hak menguasai dari negara tersebut pelaksanaannya dapat dikuasakan kepada daerah-daerah swatantra dan masyarakat-masyarakat hukum adat, sekadar diperlukan dan tidak bertentangan dengan kepentingan nasional, menurut ketentuan-ketentuan peraturan pemerintah. Demikian yang disebut dalam Pasal 2 ayat (4) Undang-Undang Nomor 5 Tahun 1960 tentang Peraturan Dasar Pokok-Pokok Agraria (“UUPA”). Selain itu, dalam Pasal 3 UUPA memang terdapat istilah "hak ulayat dan hak-hak yang serupa dengan itu".

Dalam Penjelasan Pasal 3 UUPA dijelaskan bahwa yang dimaksud dengan "hak ulayat dan hak-hak yang serupa itu" ialah apa yang di dalam perpustakaan hukum adat disebut "beschikkingsrecht".Bunyi selengkapnya Pasal 3 UUPA adalah sebagai berikut: Dengan mengingat ketentuan-ketentuan dalam pasal 1 dan 2 pelaksanaan hak ulayat dan hak-hak yang serupa itu dari masyarakat-masyarakat hukum adat, sepanjang menurut kenyataannya masih ada, harus sedemikian rupa sehingga sesuai dengan kepentingan nasional dan Negara, yang berdasarkan atas persatuan bangsa serta tidak boleh bertentangan dengan Undang-undang dan peraturan-peraturan lain yang lebih tinggi

Adapun yang dimaksud sepanjang menurut kenyataanya masih ada oleh Pasal 3 UUPA ini adalah:

Suatu masyarakat hukum adat diakui keberadaannya, jika menurut kenyataannya memenuhi unsur antara lain:

1) masyarakatnya masih dalam bentuk paguyuban (rechtsgemeenschap);

2) ada kelembagaan dalam bentuk perangkat penguasa adatnya;

3) ada wilayah hukum adat yang jelas;

4) ada pranata dan perangkat hukum, khususnya peradilan adat, yang masih ditaati; dan

5) masih mengadakan pemungutan hasil hutan di wilayah hutan sekitarnya untuk pemenuhan kebutuhan hidup sehari-hari.

Hal ini juga diperkuat dengan Pasal 18B ayat (2) UUD 1945 menyatakan bahwa negara mengakui dan menghormati kesatuan-kesatuan masyarakat hukum adat beserta hak-hak tradisionalnya sepanjang masih hidup dan sesuai dengan perkembangan masyarakat dan prinsip Negara Kesatuan Republik Indonesia. Jadi, jika ada undang-undang yang tidak mengakui keberadaan hak-hak tradisional masyarakat hukum adat, maka jelas-jelas bertentangan dengan UUD 1945. Jika kita melihat kembali lagi pada Peraturan Peraturan Presiden Nomor 86 Tahun 2018 Tentang Reforma Agraria jelas bahwa objek dari Program Redistribusi Tanah yang telah disebutkan secara jelas pada Pasal 7 bahwa objek dari Reforma Agraria adalah tanah Negara bukan tanah adat yang dilepaskan menjadi tanah Negara yang selama ini terjadi di Provinsi Papua.

Program Redistribusi Tanah di Provinsi Papua sendiri sebagaimana Penulis lihat pelaksanaanya tidak memperhatikan pada peraturan yang lebih tinggi dari Perpres Nomor 86

21 Erasmus Cahyadi, Beberapa Catatan Atas Peraturan MATR/KBPN Nomor 9 Tahun 
Tahun 2018. Sebagamana kita tahu bahwa tata-urutan dari perundang-undang sesuai dengan UU 12 Tahun 2011 Tentang Hirakhi Peraturan Perundang-undangan pada Pasal 7 ayat (1) Undang-Undang Nomor 12 Tahun 2011 tentang Pembentukan Peraturan Perundang-Undangan ("UU 12/2011") sebagaimana yang telah diubah dengan Undang-Undang Nomor 15 Tahun 2019 tentang Perubahan atas Undang-Undang Nomor 12 Tahun 2011 tentang Pembentukan Peraturan Perundang-Undangan ("UU 15/2019") yang berbunyi:

Jenis dan hierarki Peraturan Perundang-undangan terdiri atas:

1) Undang-Undang Dasar Negara Republik Indonesia Tahun 1945;

2) Ketetapan Majelis Permusyawaratan Rakyat;

3) Undang-Undang/Peraturan Pemerintah Pengganti Undang-Undang;

4) Peraturan Pemerintah;

5) Peraturan Presiden;

6) Peraturan Daerah Provinsi; dan

7) Peraturan Daerah Kabupaten/Kota.

Kekuatan hukum peraturan perundang-undangan di atas sesuai dengan hierarki tersebut dan peraturan perundang-undangan yang lebih rendah tidak boleh bertentangan dengan peraturan perundang-undangan yang lebih tinggi (UU 15 Tahun 2019,2019).

Selanjutnya jika kita melihat pada Pasal 3 UUPA sangat jelas sekali sebagaimana yang telah dijelaskan diatas bahwa Namun, pada kenyataanya ialah wilayah papua merupakan wilayah adat Masyarakat Hukum Adat di Papua, termasuk di Papua Barat, terbagi di dalam 7 (tujuh) wilayah adat. Pertama, wilayah adat I Mamta di Kota Jayapura dengan 4 suku, Kabupaten Sarmi dengan 25 suku, Kabupaten Jayapura dengan 26 suku, Kabupaten Keeron dengan 14 suku dan Kabupaten Mamberamo 14 suku. Kedua, wilayah adat II Saireri: Kabupaten Biak 2 suku, Kabupaten Nabire 4 suku, Kabupaten Yapen 15 suku, Kabupaten Teluk Wondama 10 suku dan Kabupaten Waropen 10 suku. Ketiga, wilayah adat III Bomberai, Kabupaten Manokwari 6 suku, Kabupaten Raja Ampat 7 suku, Kabupaten Sorong 14 suku, Kabupaten Teluk Bintuni 7 suku, Kabupaten Sorong Selatan 6 suku. Keempat wilayah adat IV Bomberai, Kabupaten Fak-Fak 8 suku dan Kabupaten Kaimana 8 suku. Kelima, wilayah adat V AnimHa, Kabupaten Merauke 8 suku, Kabupaten Boven Digul 10 suku, Kabupaten Asmat 7 suku, Kabupaten Mappi 4 suku. Keenam wilayah adat VI La Pago, Kabupaten Pegunungan Bintang 4 suku, KabupatenYahukimo 6 suku, Kabupaten Jayawijaya 4 suku dan Kabupaten Tolikara 5 suku. Ketujuh wilayah adat VII Mee Pago, Kabupaten Timika 3 suku, Kabupaten Puncak Jaya 6 suku dan Kabupaten Paniai 3 suku.

Kemudian, kata "memperhatikan" dalam Pasal 4 ayat (3) UU Kehutanan, sambung Mahkamah, harus dimaknai lebih tegas, yaitu negara mengakui dan menghormati kesatuankesatuan masyarakat hukum adat beserta hak-hak tradisionalnya, sejalan dengan maksud Pasal 18B ayat (2) UUD 1945. Adapun syarat pengakuan dan penghormatan masyarakat hukum adat dalam frasa "sepanjang kenyataannya masih ada dan diakui keberadaannya", harus dimaknai sepanjang masih hidup dan sesuai dengan perkembangan masyarakat, karena hukum adat pada umumnya merupakan hukum yang tidak tertulis dan merupakan living law, artinya merupakan hukum yang diterima (accepted) dan dijalankan (observed) serta ditaati oleh masyarakat yang bersangkutan karena memenuhi rasa keadilan bagi mereka dan sesuai serta diakui oleh konstitusi.

Di samping itu, berkenaan syarat sepanjang kenyataannya masih ada dan diakui keberadaannya, dalam kenyataannya status dan fungsi Tanah Ulayat dalam masyarakat hukum adat bergantung kepada status keberadaan masyarakat hukum adat. Kemungkinan yang terjadi adalah kenyataannya masih ada tetapi tidak diakui keberadaannya atau kenyataannya tidak ada tetapi diakui keberadaannya. Jika kenyataannya masih ada tetapi tidak diakui keberadaannya, hal ini dapat menimbulkan kerugian pada masyarakat yang bersangkutan. "Untuk mencegah terjadinya dampak negatif, UUD 1945 memerintahkan keberadaan dan perlindungan kesatuan-kesatuan masyarakat hukum adat supaya diatur dalam UndangUndang, agar dengan demikian menjamin adanya kepastian hukum yang berkeadilan.

Karena pada dasarnya masyarakat adat memiliki hak penuh atas tanah, wilayah dan sumber daya alam, termasuk atas hutan adat. Pengakuan terhadap hak-hak ini, merupakan 
bagian dari pemenuhan hak asasi yang melekat pada masyarakat adat dan dijamin oleh UUD 1945 dan secara nyatanya masayarakat adat di Provinsi Papua masih ada dan tersusun jelas organisasi masyarakat adatnya sesuai dengan ketentuan Pasal 3 UUPA Suatu masyarakat hukum adat diakui keberadaannya, jika menurut kenyataannya memenuhi unsur antara lain:

1) masyarakatnya masih dalam bentuk paguyuban (rechtsgemeenschap);

2) ada kelembagaan dalam bentuk perangkat penguasa adatnya;

3) ada wilayah hukum adat yang jelas;

4) ada pranata dan perangkat hukum, khususnya peradilan adat, yang masih ditaati; dan

5) masih mengadakan pemungutan hasil hutan di wilayah hutan sekitarnya untuk pemenuhan kebutuhan hidup sehari-hari.

Apalagi lagi dengan hadirnya Putusan MK Nomor 35 Tahun 2012 harus dipahami bahwa putusan MK harus dilihat utuh (holistik), bukan parsial dan sepotong-potong karena sifatnya yang final dan mengikat. Putusan MK 35 menandai babak baru pengakuan negara terhadap masyarakat adat di Indonesia. Putusan tersebut mengakui masyarakat adat sebagai "penyandang hak" atau subjek hukum atas wilayah adatnya. Dengan itu hendak dikatakan bahwa Putusan MK 35 itu adalah suatu putusan yang menjadi dasar bagi suatu penataan kembali penguasaan tanah dan sumber daya alam yang selama ini berbasis kepada negara dan kepentingan swasta. Lebih lanjut, Putusan MK 35 juga menjadi dasar bagi pemulihan hak masyarakat adat yang selama ini mengalami tekanan dari pihak luar yang membuat mereka tidak bisa memperoleh manfaat secara maksimal dari wilayah, tanah dan sumber daya yang dimilikinya (Rachman.2016) ${ }^{22}$

Padahal yang dimaksud dengan Program Redistribusi Tanah dari Pemerintah dalam hal ini adalah Kementerian Agraria dan Tata Ruang/Badan Pertanahan Nasional nerupakan konsep Reforma Agraria pada hakekatnya ialah konsep land reform, yang merupakan penataan kembali struktur penguasaan/ kepemilikan tanah yang lebih adi dan tidak merugikan pihak manapun. Seharusnya Pihak Pemerintah melakukan penelitian terlebih dahulu mengenai eksis atau tidaknya masyarakat huikum adat di suatu wilayah sesuai dengan Peraturan Menteri Dalam Negeri Nomor 52 Tahun 2014 tentang Pedoman Pengakuan dan Perlindungan Masyarakat Hukum Adat. Dalam peraturan tersebut, digunakan istilah 'wilayah adat', yaitu tanah adat yang berupa tanah, air, dan atau perairan beserta sumber daya alam yang ada di atasnya dengan batas-batas tertentu, dimiliki, dimanfaatkan dan dilestarikan secara turuntemurun dan secara berkelanjutan untuk memenuhi kebutuhan hidup masyarakat yang diperoleh melalui pewarisan dari leluhur mereka atau gugatan kepemilikan berupa tanah ulayat atau hutan adat .23

Pengakuan dan perlindungan masyarakat hokum adat dilakukan melalui tahapan, Identifikasi masyarakat hukum adat,verivikasi dan validasi masyarakat hukum adat dan penetapan masyarakat hukum adat. Dalam Pasal 5 Permendagri 52/2014 kemudian berbunyi:

1) Bupati/Walikota melalui Camat atau sebutan lain melakukan identifikasi sebagaimana dimaksud dalam pasal 3 huruf a dengan melibatkan masyarakat hukum adat atau kelompok masyarakat.

2) Identifikasi sebagaimana dimaksud pada ayat (1) dilakukan dengan mencermati:

a) sejarah Masyarakat Hukum Adat;

b) wilayah Adat;

c) hukum Adat;

d) harta kekayaan dan/atau benda-benda adat; dan

e) kelembagaan/sistem pemerintahan adat

3) Hasil identifikasi sebagaimana dimaksud pada ayat (2) dilakukan verifikasi dan validasi oleh Panitia Masyarakat Hukum Adat kabupaten/kota.

4) Hasil verifikasi dan validasi sebagaimana dimaksud pada ayat (3), diumumkan kepada Masyarakat Hukum Adat setempat dalam waktu 1 (satu) bulan.

22 Noer Fauzi Rahman, Masyarakat Hukum Adat dan Hak Kumunal atas Tanah, Jurnal Digest Epistema Berkala Isu Hukum dan Keadilan Eko-sosial, Vol.6/2016,hlm.7

23 Lihat Permendagri Nomor 52 Tahun 2014 
Kosmik Hukum Vol. 20 No. 1 (2020): 64-71

E-ISSN: 2655-9242 | P-ISSN: 1411-9781

DOI: 10.30595/kosmikhukum.v20i1.8625

Panitia masyarakat hukum adat kabupaten/kota yang dibentuk untuk melakukan pengakuan dan perlindungan masyarakat hukum adat, menyampaikan rekomendasi kepada bupati/walikota berdasarkan hasil verifikasi dan validasi.Bupati/walikota melakukan penetapan pengakuan dan perlindungan masyarakat hukum adat berdasarkan rekomendasi panitia masyarakat hukum adat dengan keputusan kepala daerah(Permendagri 52/2014, 2014)

Pada praktiknya pelaksanaan Program Reforma Agraia tidak sesuai dengan peraturan perundang-undangan yang berlaku. Dimana Program Redistribusi Tanah yang ada di Provinsi Papua pada tahun 2019 telah di target sebanyak 11.000 bidang tanah adapaun yang menjadi objeknya rata-rata adalah Tanah Ulayat yang dilepaskan menjadi Tanah Negara hal demikian menurut Penulis merupakan perbuatan hukum yang inkonsistensi atau bertentangan dengan amanat UUD 1945 khusunya Pasal 18 B Ayat 2 dimana bunyi dari Pasal tersebut adalah negara mengakui dan menghormati kesatuan-kesatuan masyarakat hukum adat beserta hak-hak tradisionalnya, sejalan dengan maksud Pasal 18B ayat (2) UUD 1945. Adapun syarat pengakuan dan penghormatan masyarakat hukum adat dalam frasa "sepanjang kenyataannya masih ada dan diakui keberadaannya", harus dimaknai sepanjang masih hidup dan sesuai dengan perkembangan masyarakat, karena hukum adat pada umumnya merupakan hukum yang tidak tertulis dan merupakan living law, artinya merupakan hukum yang diterima (accepted) dan dijalankan (observed) serta ditaati oleh masyarakat yang bersangkutan karena memenuhi rasa keadilan bagi mereka dan sesuai serta diakui oleh konstitusi.

Dilihat dari implikasinya saja sudah tidak relevan jika retribusi tanah dilaksanakan pada Provinsi Papua. Karena setelah dikaji secara seksama dengan lihat sendiri pelaksanaanya tidak memperhatikan pada peraturan yang lebih tinggi. Sebagamana kita tahu bahwa tata-urutan dari perundang-undang sesuai dengan UU 12 Tahun 2011 Tentang Hirakhi Peraturan Perundang-undangan pada Pasal 7 ayat (1) Undang-Undang Nomor 12 Tahun 2011 tentang Pembentukan Peraturan Perundang-Undangan ("UU 12/2011") sebagaimana yang telah diubah dengan Undang-Undang Nomor 15 Tahun 2019 tentang Perubahan atas UndangUndang Nomor 12 Tahun 2011 tentang Pembentukan Peraturan Perundang-Undangan ("UU 15/2019") yang berbunyi:

Jenis dan hierarki Peraturan Perundang-undangan terdiri atas:

1) Undang-Undang Dasar Negara Republik Indonesia Tahun 1945;

2) Ketetapan Majelis Permusyawaratan Rakyat;

3) Undang-Undang/Peraturan Pemerintah Pengganti Undang-Undang;

4) Peraturan Pemerintah;

5) Peraturan Presiden;

6) Peraturan Daerah Provinsi; dan

7) Peraturan Daerah Kabupaten/Kota.

Kekuatan hukum peraturan perundang-undangan di atas sesuai dengan hierarki tersebut dan peraturan perundang-undangan yang lebih rendah tidak boleh bertentangan dengan peraturan perundang-undangan yang lebih tinggi. Aturan yang tidak konsisten ini terlihat pada pelaksanaaan program redistribusi di tanah Papua padahal sudah jelas bahwa masyrakat adat di Papua masih jelas ada eksistensinya dan struktur organisasinya juga lengkap tetapi kenyataanya malah tanah tersebut di paksakan untuk dilepaskan ke Negara demi melencarkan Program Redistribusi Tanah yang merupakan bentuk dari Program Reforma agrarian tersbut.

Apalagi ditarget 11.000 bidang pada tahun 2019 lalu ini jelas merupakan perbuatan hukum yang inkonsistensi atau bertentangan dengan dengan Pasal 18B ayat (2) UUD 1945 menyatakan bahwa negara mengakui dan menghormati kesatuan-kesatuan masyarakat hukum adat beserta hak-hak tradisionalnya sepanjang masih hidup dan sesuai dengan perkembangan masyarakat dan prinsip Negara Kesatuan Republik Indonesia. Jadi, jika ada undang-undang yang tidak mengakui keberadaan hak-hak tradisional masyarakat hukum adat, maka jelas-jelas bertentangan dengan UUD 1945 begitupula dengan UUPA 5 Tahun 1960 Pasal 3. Jika kita melihat kembali lagi pada Peraturan Peraturan Presiden Nomor 86 Tahun 2018 Tentang Reforma Agraria disebutkan secara jelas objek dari Program Redistribusi Tanah pada Pasal 7 
bahwa objek dari Reforma Agraria adalah tanah Negara bukan tanah adat yang dilepaskan menjadi tanah Negara yang selama ini terjadi di Provinsi Papua.

Dengan demikian Program Reforma Agraria yang sejatinya adalah untuk menciptakan keadilan bagi masyarakat papua malah membuat petaka bagi pemerintah sendiri karena ditakutkan adanya kepentingan pada proyek tersebut. Karena pada dasarnya apabila program ini tetap dilanjutkan maka akan membuat kerugian bagi masyrakat papua yaitu hilangnya tanah ulayat di Provinsi Papua yang merupakan tanah sebagai "dusun", "dapur", "tempat tumpah darah", dan tanah sebagai "ibu". Sedangkan secara religius-magis, tanah memiliki nilai tertinggi dari sumber segala ciptaan dan penguasaan alam dan pemberian hidup dari Tuhan . Tanah menurut Orang Papua identik dengan kehidupan, maka diberi simbol sebagai seorang ibu atau mama yang selalu mengayomi, melindungi dan membesarkan seorang bayi, kanakkanak sampai dewasa. Misalnya orang Kamoro menyebut tanah sebagai "Enai Tapare", orang Meybrat menyebut "Tabam Ramu" atau tanah kami/tanah ibu.

\section{Penutup}

\section{Kesimpulan}

penguasaan, pemilikan, penggunaan, dan pemanfaatan tanah untuk menjamin terwujudnya keadilan dan kepastian hukum dalam penguasaan, pemilikan, penggunaan, dan pemanfaatan tanah. Pelaksanaan Reforma Agraria di Indonesia menekankan pada konsep redistribusi tanah dengan membagikan tanah yang dikuasai Negara, tanah kelebihan luas maksimum, tanah absentee, dan tanah Negara lainnya yang telah ditetapkan menjadi tanah objek Reforma Agraria kepada petani penggarap dan petani lahan sempit. Namun, realitanya Program Redistribusi Tanah di Provinsi Papua sendiri sebagaimana Penulis lihat pelaksanaanya tidak memperhatikan pada peraturan yang lebih tinggi dari Perpres Nomor 86 Tahun 2018. Dalam Penjelasan Pasal 3 UUPA dijelaskan bahwa yang dimaksud dengan "hak ulayat dan hak-hak yang serupa itu" ialah apa yang di dalam perpustakaan hukum adat disebut "beschikkingsrecht". Bunyi selengkapnya Pasal 3 UUPA adalah sebagai berikut: Dengan mengingat ketentuan-ketentuan dalam pasal 1 dan 2 pelaksanaan hak ulayat dan hak-hak yang serupa itu dari masyarakat-masyarakat hukum adat, sepanjang menurut kenyataannya masih ada, harus sedemikian rupa sehingga sesuai dengan kepentingan nasional dan Negara, yang berdasarkan atas persatuan bangsa serta tidak boleh bertentangan dengan Undang-undang dan peraturan-peraturan lain yang lebih tinggi. Pada praktiknya pelaksanaan Program Reforma Agraia di Provinsi Papua tidak sesuai dengan peraturan perundang-undangan yang berlaku. Dimana Program Redistribusi Tanah yang ada di Provinsi Papua pada tahun 2019 telah di target sebanyak 11.000 bidang tanah adapaun yang menjadi objeknya rata-rata adalah Tanah Ulayat yang dilepaskan menjadi Tanah Negara hal demikian menurut Penulis merupakan perbuatan hukum yang inkonsistensi atau bertentangan dengan amanat UUD 1945 khusunya Pasal 18 B Ayat 2 dimana bunyi dari Pasal tersebut adalah negara mengakui dan menghormati kesatuan-kesatuan masyarakat hukum adat beserta hak-hak tradisionalnya, sejalan dengan maksud Pasal 18B ayat (2) UUD 1945. Adapun syarat pengakuan dan penghormatan masyarakat hukum adat dalam frasa "sepanjang kenyataannya masih ada dan diakui keberadaannya", harus dimaknai sepanjang masih hidup dan sesuai dengan perkembangan masyarakat, karena hukum adat pada umumnya merupakan hukum yang tidak tertulis dan merupakan living law, artinya merupakan hukum yang diterima (accepted) dan dijalankan (observed) serta ditaati oleh masyarakat yang bersangkutan karena memenuhi rasa keadilan bagi mereka dan sesuai serta diakui oleh konstitusi.

\section{Saran}

Seharusnya Program Redistribusi Tanah di Provinsi Papua ini tidak bisa dilaksanakan karena wilayah papua merupakan wilayah adat. Dengan demikian, apabila program ini harus tetap berjalan Penulis menyarankan agar yang menjadi objek reforma agraria bukan merupakan tanah adat yang dilepaskan ke tanah Negara melainkan tanah hasil dari jual- beli, 
Kosmik Hukum Vol. 20 No. 1 (2020): 64-71

E-ISSN: 2655-9242 | P-ISSN: 1411-9781

DOI: $10.30595 /$ kosmikhukum.v20i1.8625

tanah transmigran ataupun jika terpaksa harus tanah adat maka perbuatan hukum yang harus dilakukan adalah kita hanya perlu mengakui hak ulayat yang dimiliki masyarakat adat dengan cara mencatatnya saja pada administrasi kantor peranahan bukan dengan diterbitkan sertipikat tanah. Hal itu sama saja menghilangkan hak yang sudah dimiliki masyarakat adat sejak turunmenurun dari nenek moyang dan sama saja ada potensi menghilangkan masyarakat hokum adat yang sudah terbentuk sebelum adanya peraturan per undang-undangan.

\section{Daftar Pustaka}

Asshiddiqie, Jimly. "The Rule Of Law" di Indonesia Pasca Reformasi",Sinar grafika, Jakarta, 2015

Asshiddiqie, Jimly, "Negara Hukum Indonesia", http:// www.jimly.com, diakses pada tanggal 3 Maret 2015

Gefilem, Maria Fanisa, Pelepasan Tanah Adat Suku Moi Di Kota Sorong Provinsi Papua Barat Berdasarkan Peraturan Pemerintah Nomor 24 Tahun 1997 Tentang Pendaftaran Tanah". Lex Crimen Vol. V/No. 3/Mar/2016, 2016

Bawono, Adi Candro. Pengakuan Hak Ulayat, Hukum Online, Jakarta, 2019;

Marzuki, Peter Mahmud. Penelitian Hukum, Kencana, Jakarta, 2013;

Soekanto, Soerjono dan Mamudji, Sri. Penelitian Hukum Normatif, PT Raja Grafindo Persada, Jakarta, 2012

Pide, Suryaman Mustari. Hukum Adat Dahulu, Kini, dan Akan Datang, Kencana, Jakarta, 2017

Rosmidah, Pengakuan Hukum Terhadap Hak Ulayat Masyarakat Hukum Adat Dan Hambatan Implementasinya, Jurnal Digest Epistema Berkala Isu Hukum dan Keadilan Eko-sosial, 2015

Fatimah, Reforma Agraria Dalam Konteks Peningkatan Akses Kaum Tani Miskin Terhadap Penguasaan Tanah di Indonesia, Jurnal Hukum Samudra Keadilan.Vol.10

Sapradi, Redistribusi Tanah Negara Objek Landreform Dalam Mendukung Program Reforma Agraria Di kabupaten Sumbawa, Jurnal Kajian Hukum dan Keadilan,2015

Nia Kurniati, Penataan Penguasaan Tanah Milik Adat Melalui Pelaksanaan Kebijakan Land Reform (Studi Kasus di Kabupaten Buru Selatan), Jurnal Bina Hukum Vol.4 No.1,2019

Majelis Rakyat Papua, http:/ /mrp.papua.go.id., Diakses pada tanggal 15 September 2020

Reba, Yusak Elisa. Pengakuan Tanah Ulayat Di Papua dan kaitanya dengan Permen Hak Kumunal Atas Tanah, Jurnal Digest Epistema Berkala Isu Hukum dan Keadilan Ekososial, Vol.6/2016.

Cahyadi, Erasmus. Beberapa Catatan Atas Peraturan MATR/KBPN Nomor 9 Tahun 2015, Kencana, Jakarta ,2015

Rahman, Noer Fauzi. Masyarakat Hukum Adat dan Hak Kumunal atas Tanah, Jurnal Digest Epistema Berkala Isu Hukum dan Keadilan Eko-sosial, Vol.6/2016 